Quarterly Progress Report

July 18, 2000

\title{
Biological Monitoring Program for East Fork Poplar Creek
}

\author{
Submitted to \\ M. C. Wiest \\ Environment, Safety and Health Organization \\ Lockheed Martin Energy Systems \\ Prepared by \\ Oak Ridge National Laboratory \\ Environmental Sciences Division \\ Oak Ridge, Tennessee 37831 \\ Managed by UT-Battelle, LLC, \\ for the \\ U.S. Dept. of Energy \\ under contract DE-AC05-00OR22725 \\ Contributors: \\ S. M. Adams \\ S. W. Christensen \\ M. S. Greeley, Jr. \\ W. R. Hill \\ J. F. McCarthy \\ M. J. Peterson \\ M. G. Ryon \\ J. G. Smith \\ G. R. Southworth \\ A. J. Stewart
}




\section{DISCLAIMER}

This report was prepared as an account of work sponsored by an agency of the United States Government. Neither the United States Government nor any agency thereof, nor any of their employees, makes any warranty, express or implied, or assumes any legal liability or responsibility for the accuracy, completeness, or usefulness of any information, apparatus, product, or process disclosed, or represents that its use would not infringe privately owned rights. Reference herein to any specific commercial product, process, or service by trade name, trademark, manufacturer, or otherwise, does not necessarily constitute or imply its endorsement, recommendation, or favoring of the United States Government or any agency thereof. The views and opinions of authors expressed herein do not necessarily state or reflect those of the United States Government or any agency thereof. 


\section{INTRODUCTION}

In May 1985, a National Pollutant Discharge Elimination System (NPDES) permit was issued for the Oak Ridge Y-12 Plant. As a condition of the permit, a Biological Monitoring and Abatement Program (BMAP) was developed to demonstrate that the effluent limitations established for the Y-12 Plant protect the classified uses of the receiving stream (East Fork Poplar Creek; EFPC), in particular, the growth and propagation of aquatic life (Loar et al. 1989). A second objective of the BMAP is to document the ecological effects resulting from the implementation of a water pollution control program designed to eliminate direct discharges of wastewaters to EFPC and to minimize the inadvertent release of pollutants to the environment. Because of the complex nature of the discharges to EFPC and the temporal and spatial variability in the composition of the discharges, a comprehensive, integrated approach to biological monitoring was developed. A new permit was issued to the Y-12 Plant on April 28, 1995 and became effective on July 1, 1995. Biological monitoring continues to be required under the new permit. The BMAP consists of four major tasks that reflect different but complementary approaches to evaluating the effects of the Y-12 Plant discharges on the aquatic integrity of EFPC. These tasks are (1) toxicity monitoring, (2) biological indicator studies, (3) bioaccumulation studies, and (4) ecological surveys of the periphyton, benthic macroinvertebrate, and fish communities.

Monitoring is currently being conducted at five primary EFPC sites, although sites may be excluded or added depending upon the specific objectives of the various tasks. Criteria used in selecting the sites include: (1) location of sampling sites used in other studies, (2) known or suspected sources of downstream impacts, (3) proximity to U.S. Department of Energy (DOE) Oak Ridge Reservation (ORR) boundaries, (4) concentration of mercury in the adjacent floodplain, (5) appropriate habitat distribution, and (6) access. The primary sampling sites include upper EFPC at kilometers (EFKs) 24.4 and 23.4 [upstream and downstream of Lake Reality (LR) respectively]; EFK 18.7 (also EFK 18 and 19), located off the ORR and below an area of intensive commercial and light industrial development; EFK 13.8 (also EFK 14), located upstream from the Oak Ridge Wastewater Treatment Facility (ORWTF); and EFK 6.3 located approximately $1.4 \mathrm{~km}$ below the ORR boundary (Fig. 1.1). Brushy Fork (BF) at kilometer (BFK) 7.6 is used as a reference stream in most tasks of the BMAP. Additional sites off the ORR are also occasionally used for reference, including Beaver Creek, Bull Run, Hinds Creek, Paint Rock Creek, and the Emory River in Watts Bar Reservoir (Fig. 1.2).

\section{TOXICITY MONITORING (M. S. Greeley, Jr. and A. J. Stewart)}

\subsection{Introduction}

The ambient toxicity monitoring task includes three subtasks: toxicity monitoring, toxicity experiments, and supporting studies. Toxicity monitoring uses U.S. Environmental Protection Agency (EPA) approved methods with Ceriodaphnia dubia and fathead larvae to provide systematic information that can be used to determine changes in the biological quality of EFPC through time. Toxicity experiments are conducted to test specific hypotheses about stream water quality. These hypotheses are addressed experimentally by the systematic application of ambient toxicity test methods. Supporting studies, often conducted using cost-effective student interns, are used to (1) investigate the relationship between the physicochemical and biological conditions in EFPC, particularly as they relate to processes or rates of ecological recovery and (2) develop better methods for accurately predicting ecological recovery accompanying changes in water quality in EFPC. Toxicity monitoring at EFK 24.1, a site just upstream of 


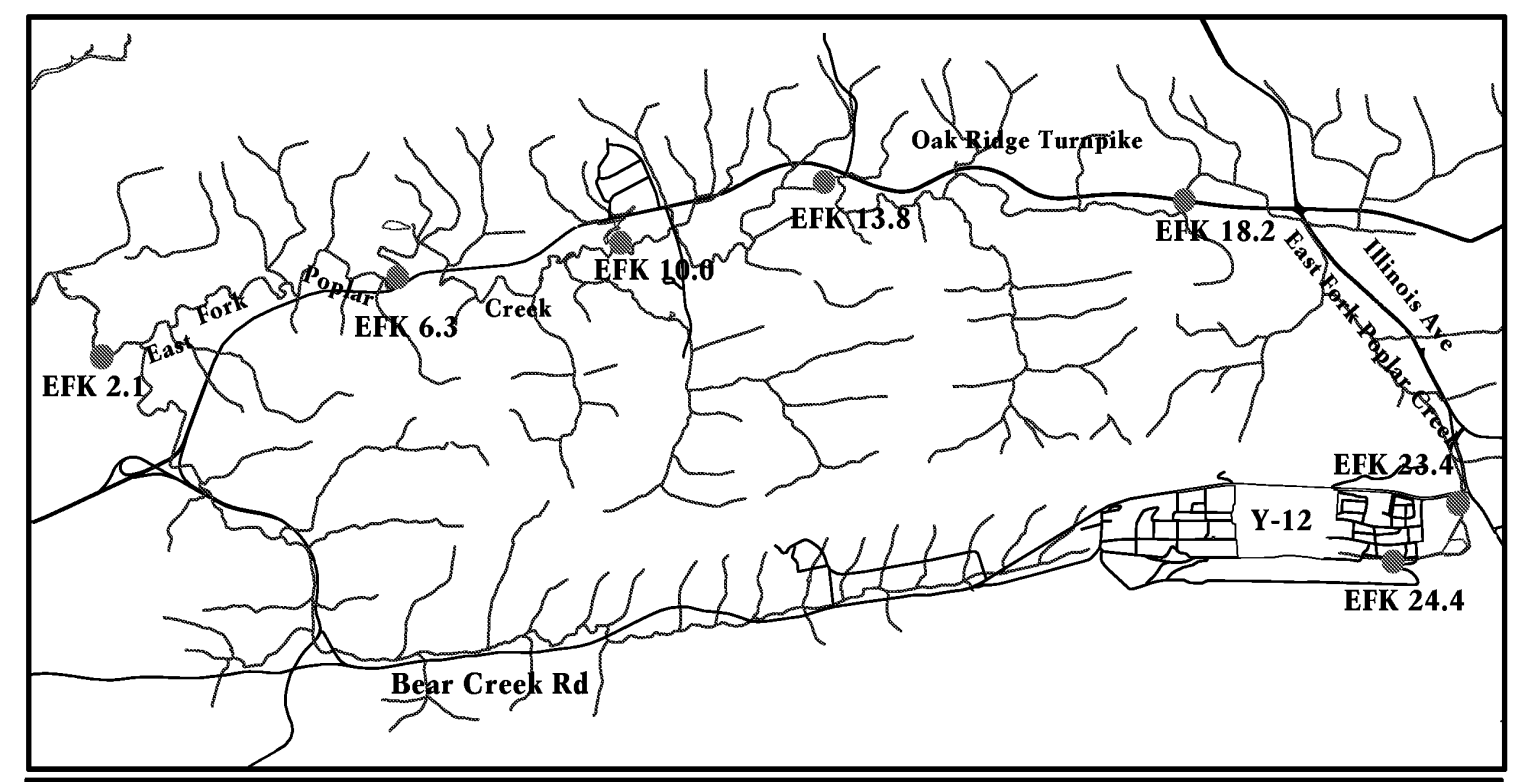

Y-12 Biological Monitoring and

Abatement Program

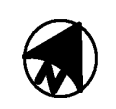

Scale

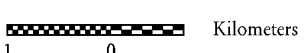

\begin{tabular}{|c||}
\hline \multicolumn{1}{|c||}{ LEGEND } \\
\hline SFK \# $\quad$ Sampling Location \\
Eest Fork Kilometer \\
\hline Tennessee State Plane Coordinate System, NAD 83 \\
\hline Source: Stream boundarys provided by the Oak \\
Ridge Environmental Resources \\
Information System (OREIS). \\
Prepared by Y-12 Biological Monitoring and \\
Abatement Program \\
Created: $95-12-12.13: 25$.Tues Version 1.0 \\
\hline
\end{tabular}

Figure 1.1. Location of biological monitoring sites on East Fork Poplar Creek in relation to the Oak Ridge Y-12 National Security Complex. 
O7NL-DWG-95M-7421గ

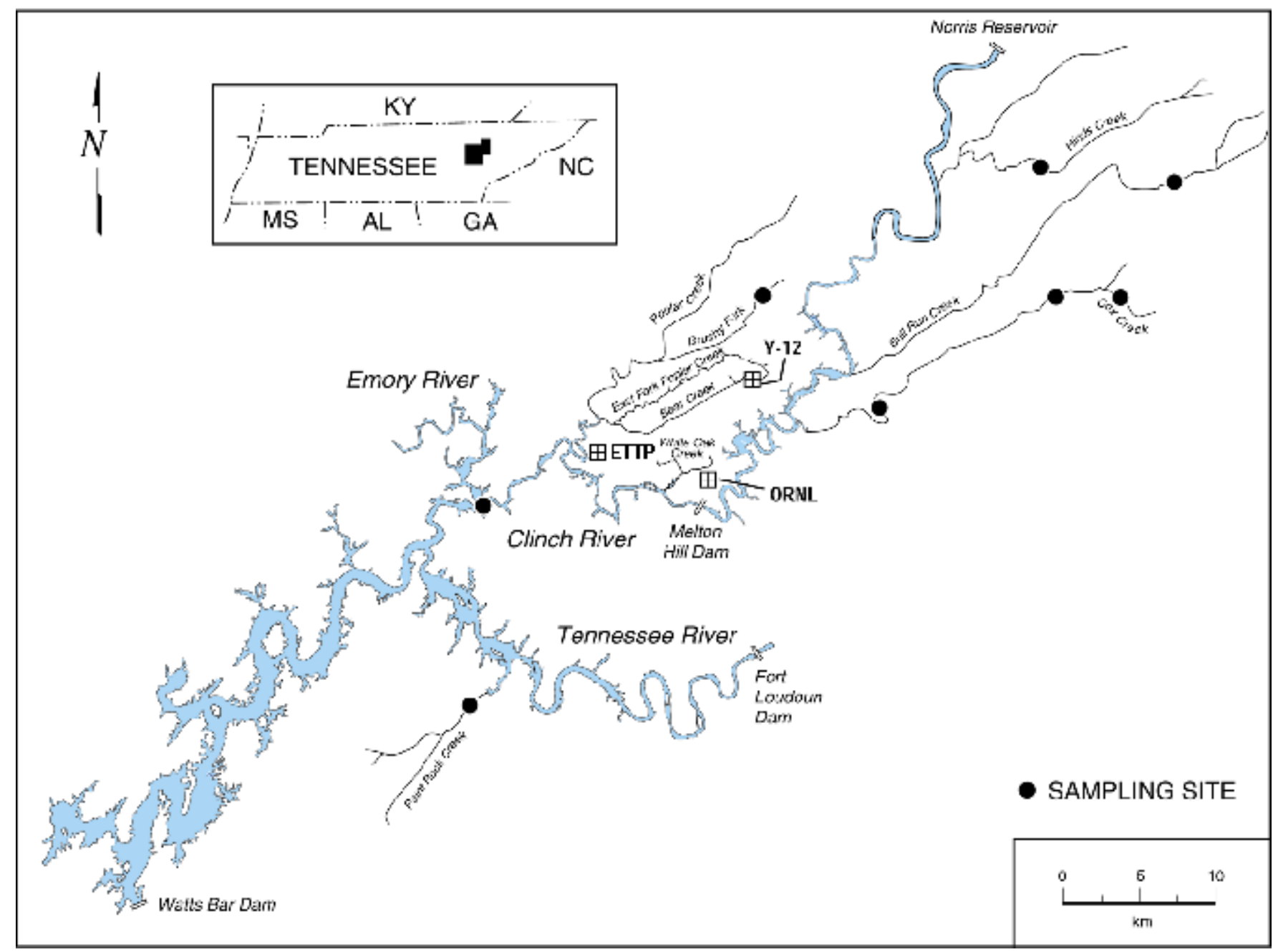

Figure 1.2. Location of biological monitoring reference sites in relation to the Oak Ridge Y-12 National Security Complex. 
Lake Reality, is conducted quarterly. Monitoring of EFK 23.8, immediately downstream of Lake Reality, has been discontinued as the bypass of Lake Reality made this site nearly synonymous with EFK 24.1. As required by the Y-12 Plant's National Pollutant Discharge Elimination System (NPDES) permit, quarterly toxicity tests with fathead minnows and Ceriodaphnia are conducted at Outfall 201 (an instream NPDES location in upper EFPC). The Outfall 201 tests meet the intent of the BMAP Plan to conduct quarterly toxicity tests at a nearby location, EFK 25.1. The results of the Outfall 201 tests are reported both here and on Discharge Monitoring Reports issued by the Y-12 Plant to the Tennessee Department of Environment and Conservation.

\subsection{Results/Progress}

\subsubsection{Toxicity monitoring}

Ambient water samples from EFK 24.1 and effluent samples from Outfall 201 were evaluated for toxicity to Ceriodaphnia dubia during April 12-19, 2000. On each sampling day, grab samples of stream water or 24-h time-proportional composite samples from Outfall 201 were collected for testing. Results of the toxicity tests and attendant water-quality chemical analyses are shown in Tables 2.1 and 2.2. During the test period, Ceriodaphnia survival was $100 \%$ in all samples. Ceriodaphnia reproduction in the stream water or effluent samples was not significantly different from the control. Samples from Outfall 201 were also evaluated for toxicity to fathead minnows (Pimephales promelas). Mean survival was $100 \%$ in both 80 and $100 \%$ concentrations, and growth in both concentrations $(0.74 \mathrm{mg} /$ larvae $)$ exceeded growth of minnows in the control water $(0.70 \mathrm{mg} / \mathrm{larvae})$.

Table 2.1. Results of Ceriodaphnia dubia toxicity tests of ambient sites from East Fork Poplar Creek and Outfall 201 conducted April12-19, 2000

\begin{tabular}{cccc}
\hline Sample & Concentration $(\%)$ & Survival $(\%)$ & $\begin{array}{c}\text { Mean Reproduction } \\
\text { (offspring/surviving female } \pm \text { SD) }\end{array}$ \\
\hline Control & 100 & Ambient sites & \\
EFK 24.1 & 100 & 100 & $23.6 \pm 2.4$ \\
Control & 100 & 100 & $23.1 \pm 2.5$ \\
Outfall 201 & 100 & 100 & $23.6 \pm 2.4$ \\
Outfall 201 & 80 & 100 & $24.3 \pm 2.0$ \\
\hline
\end{tabular}

Note: $\mathrm{EFK}=$ East Fork Poplar Creek kilometer. SD = standard deviation. 
Table 2.2. Summary (mean \pm SD) of water chemistry analyses conducted during toxicity tests of ambient samples from East Fork Poplar Creek, April 12-19, 2000

\begin{tabular}{ccccc}
\hline Sample & $\begin{array}{c}\mathrm{pH} \\
\mathrm{su})\end{array}$ & $\begin{array}{c}\text { Alkalinity } \\
\left(\mathrm{mg} / \mathrm{L} \text { as } \mathrm{CaCO}_{3}\right)\end{array}$ & $\begin{array}{c}\text { Hardness } \\
\left(\mathrm{mg} / \mathrm{L} \text { as } \mathrm{CaCO}_{3}\right)\end{array}$ & $\begin{array}{c}\text { Conductivity } \\
(\mu \mathrm{S} / \mathrm{cm})\end{array}$ \\
\hline Control & $8.17 \pm 0.10$ & $83.8 \pm 1.0$ & $99.0 \pm 1.1$ & $203.5 \pm 4.0$ \\
Outfall 201 & $7.92 \pm 0.12$ & $96.0 \pm 14.0$ & $121.0 \pm 13.0$ & $252.7 \pm 26.1$ \\
EFK 24.1 & $7.94 \pm 0.19$ & $107.0 \pm 8.7$ & $140.3 \pm 10.0$ & $304.2 \pm 14.4$ \\
\hline
\end{tabular}

Note $:$ EFK = East Fork Poplar Creek kilometer. SD = standard deviation.

\subsubsection{Special Studies}

There were no toxicity special study activities to report for this quarter.

\section{BIOLOGICAL INDICATOR MONITORING}

\subsection{Bioindicators of Fish Health (S. M. Adams)}

\subsubsection{Introduction}

This task involves the use and application of bioindicators of fish health, in addition to other investigative approaches, to evaluate the effects of water quality and other environmental variables on fish in EFPC. A suite of diverse bioindicators of fish health has been monitored since fall 1985 to evaluate the health of a sentinel species, the redbreast sunfish (Lepomis auritus), as a component of the BMAP program.

\subsubsection{Results/Progress}

Annual Sampling - The annual BMAP monitoring for fish health was conducted at three sites in EFPC and at two reference sites during May and June 2000. Fish sampling was coordinated with the Bioaccumulation and Reproductive Health tasks of BMAP to reduce potential impacts of fish removal on redbreast sunfish populations in EFPC, and to associate health and reproductive status with bioaccumulation. Approximately 16 individual redbreast sunfish of each sex were collected from each site for the bioindicator studies. In addition, scales were taken for age and growth studies from 5 fish of each centimeter size group and returned alive back to the stream at the location of capture. Fish returned alive to the laboratory were processed for the normal complement of bioindicators including biochemical, histopathological, organ dysfunction, lipid dynamics, various condition indices, and several measures of reproductive competence. A subsample of 5-7 fish from each site was further processed for contaminant analysis by personnel of the Bioaccumulation task. 


\subsection{Bioindicators of Reproductive Competence (M. S. Greeley, Jr.)}

\subsubsection{Introduction}

Successful reproduction of fish populations requires that adult fish be capable of producing and spawning viable gametes. To address the reproductive competence of fish in EFPC, various reproductive indicators, representing several different levels of reproductive organization related to gamete production, have been routinely examined in redbreast sunfish sampled from EFPC and reference streams at the beginning of each annual breeding season since 1988. Establishment and maintenance of stable fish populations also require that offspring be able to develop normally into subsequent reproductive cohorts. Beginning in 1990, water samples from several sites in EFPC and other streams on and about the ORR have been tested for their effects on fish developmental processes utilizing a variation of an EPAstandard medaka (Oryzias latipes) fish embryo-larval test (Benoit et al., 1991).

\subsubsection{Results/Progress}

Annual Monitoring for Reproductive Health - As indicated in Section 3.1, annual BMAP monitoring of fish health and reproductive competence was conducted at three sites in EFPC and at two reference sites during May and June 2000. Samples from this monitoring effort are currently being analyzed; results will be presented in later quarterly reports as analyses are completed.

\section{BIOACCUMULATION MONITORING}

\subsection{Routine Bioaccumulation Monitoring (M. J. Peterson and G. R. Southworth)}

\subsubsection{Introduction}

Bioaccumulation monitoring of EFPC has identified mercury and polychlorinated biphenyls (PCBs) as substances that accumulate to concentrations in fish that may pose health concerns to human consumers. Redbreast sunfish are collected twice annually from the mid to upper reaches of EFPC to evaluate spatial and temporal trends in mercury and PCB contamination. On an annual basis, largemouth bass (Micropterus salmoides) are collected to evaluate the maximum human health risks in EFPC and stoneroller minnows (Campostoma anomalum) are collected to evaluate the potential ecological concerns due to metal accumulation.

\subsubsection{Results/Progress}

The routine spring collection of sunfish for bioaccumulation monitoring was conducted in May and June 2000 in conjunction with fish collection for the BMAP bioindicators task. Sunfish were collected from six sites in EFPC and the Hinds Creek reference stream. The EFPC sunfish samples were processed and submitted to the analytical laboratory for mercury and PCB analysis.

Results of sunfish mercury and PCB monitoring conducted in fall 1999 are presented in Tables 4.1 and 4.2. Mercury concentrations were somewhat lower at most sites than was observed in the previous year, but generally fell within ranges considered 'typical' of those sites. The notable exception 
Table 4.1. Average ( $\pm \mathrm{SE})$ concentrations of mercury $(\mu \mathrm{g} / \mathrm{g}$, wet wt.) in muscle tissue of redbreast sunfish (Lepomis auritus) collected from East Fork Poplar Creek and Hinds Creek, December 1998 - December 1999

\begin{tabular}{lccc}
\hline Site & December 1998 & May 1999 & December 1999 \\
\hline EFK 24.5 & $0.57 \pm 0.07$ & $0.91 \pm 0.17$ & $0.40 \pm 0.07$ \\
EFK 24.0 (Lake Reality) & $0.71 \pm 0.08$ & $0.50 \pm 0.10$ & $0.17 \pm 0.04^{\mathrm{a}}$ \\
EFK 23.4 & $0.83 \pm 0.18$ & $0.86 \pm 0.05$ & $0.48 \pm 0.08$ \\
EFK 18.2 & $0.97 \pm 0.12$ & $0.83 \pm 0.07$ & $0.45 \pm 0.05$ \\
EFK 13.8 & $1.11 \pm 0.12$ & $0.92 \pm 0.05$ & $0.76 \pm 0.09$ \\
EFK 6.3 & $0.94 \pm 0.16$ & $1.10 \pm 0.07$ & $0.57 \pm 0.14$ \\
Hinds Creek & $0.06 \pm 0.01$ & $0.06 \pm 0.01$ & $0.06 \pm 0.01$ \\
\hline
\end{tabular}

a Bluegill sunfish (Lepomis macrochirus)

Table 4.2. Average ( \pm SE) concentrations $(\mu \mathrm{g} / \mathrm{g}$, wet wt.) of total PCBs (Arochlor $1254+1260)$ in muscle tissue of redbreast sunfish (Lepomis auritus) collected from East Fork Poplar Creek and reference streams, December 1998 - December 1999

\begin{tabular}{lccc}
\hline Site & December 1998 & May 1999 & December 1999 \\
\hline EFK 24.2 to 24.5 & $2.49 \pm 0.40$ & $1.67 \pm 0.41$ & $1.42 \pm 0.29$ \\
EFK 24.0 (Lake Reality) & $3.77 \pm 1.13^{\mathrm{a}}$ & $1.59 \pm 0.33^{\mathrm{b}}$ & $1.83 \pm 0.58^{\mathrm{c}}$ \\
EFK 23.4 & $1.35 \pm 0.49$ & $0.86 \pm 0.10$ & $1.25 \pm 0.30$ \\
EFK 18.2 & $0.34 \pm 0.05$ & $0.15 \pm 0.01$ & $0.34 \pm 0.04$ \\
EFK 13.8 & $0.25 \pm 0.03$ & $0.25 \pm 0.05$ & $0.31 \pm 0.05$ \\
EFK 6.3 & $0.19 \pm 0.02$ & $0.17 \pm 0.02$ & $0.25 \pm 0.06$ \\
Hinds Creek & $<0.01$ & $<0.01$ & $<0.01$ \\
\hline
\end{tabular}

Note: $\mathrm{EFK}=$ East Fork kilometer. $\mathrm{N}=6$ fish/site. Some fish were collected slightly prior to or after the month shown.

${ }^{a}$ Two of six fish were bluegill (Lepomis macrochirus).

$\mathrm{b}$ Four of six fish were bluegill

c All six fish were bluegill. 
was Lake Reality, where the average mercury concentration in bluegill (Lepomis macrochirus) (redbreast sunfish abundance has dropped at this site to where it is difficult to obtain adequate numbers for monitoring) was much lower than typical of previous monitoring. Mean mercury in sunfish from Lake Reality dropped from 0.71 to $0.17 \mu \mathrm{g} / \mathrm{g}$ over the year following the full bypass of EFPC around the pond. If this change persists in future monitoring, it would indicate that the elimination of daily fresh inputs of inorganic mercury had a profound effect on the bioaccumulation of methylmercury by fish in Lake Reality despite the high concentrations of mercury that remained in the pond sediments. Such a finding would indicate that actions taken to reduce concentrations of 'dissolved' or 'bioavailable' mercury in upper EFPC might effectively reduce bioaccumulation without necessarily reducing overall total mercury concentration or loading

PCB concentrations show little change from previous monitoring. Mean concentrations are highest in upper EFPC and decrease strikingly within several kilometers downstream from Station 17. The bypass of Lake Reality appeared to have little impact on PCB concentrations in fish. This is consistent with the facile exchange of PCBs between particulate and waterborne phases, which makes resuspension of PCB-contaminated sediments a potential continuing source of PCBs to the overlying water after upstream sources are eliminated.

\subsection{Special mercury studies}

A paper entitled "Mercury and methylmercury relationships in contaminated streams in the southeastern USA" by G.R Southworth, M.A. Bogle, and R.R. Turner was submitted for publication in the proceedings of the International Conference on Heavy Metals in the Environment, to be held in Ann Arbor, MI in August 2000. Based on BMAP studies of the relationship between inorganic mercury and methylmercury in EFPC and other streams, this paper illustrates how the availability of mercury for methylation in EFPC appears to be much lower than in other chemically and ecologically similar streams.

\subsection{PCB Source Identification (J. F. McCarthy)}

\subsubsection{Introduction}

Passive monitoring of polychlorinated biphenyls (PCB) using semipermeable membrane devices (SPMD) is being employed to determine the sources and sinks of PCBs at the Y-12 Plant.

\subsubsection{Results/Progress}

Principal Components Analysis (PCA) of the "fingerprints" of PCB congeners is being conducted to better identify the sources of PCBs entering upper EFPC. Extracted and purified samples of SPMD samples collected in 1996, 1997, 1998, and 1999 have been reanalyzed by GC-MS to determine the concentrations of specific congeners. These data (approximately 30 sample locations for each year, with 3 replicates per sample, and quantifying more than 90 individual congeners per analysis) have been entered into spreadsheets and are being prepared as data-sets for PCA analysis. Results of this analysis are expected to distinguish congener profiles from, for example, outfalls entering upper EFPC, compared to profiles of PCBs derived from non-point sources within the streambed. These data will more explicitly identify PCB sources and provide a basis for rational cost-benefit decisions for remediating the stream. 


\section{COMMUNITY STUDIES}

\subsection{Periphyton (W. R. Hill)}

\subsubsection{Introduction}

Periphyton monitoring in EFPC occurs four times a year (as close to a quarterly sampling regime as environmental conditions will allow). Rocks and their associated periphyton are collected from three sites on EFPC (EFKs 24.4, 23.4, 6.3) and one site on Brushy Fork (BFK 7.6). Four rocks from each site are used in determining algal biomass (chlorophyll $a$ or chla) and the rate of photosynthesis $\left({ }^{14} \mathrm{C}\right.$ incorporation). To compare photosynthesis (PS) rates for periphyton among sites with different areal biomass, the PS data are divided by the chlorophyll $a$ amounts. The resulting chlorophyll-specific photosynthetic rates provide an index of physiological condition of the algal component of the periphyton.

\subsubsection{Results/Progress}

Periphyton biomass and photosynthesis were measured on May 16, 2000. The results of these measurements appear in Table 5.1. Chlorophyll $a$, photosynthesis, and chlorophyll-specific photosynthesis in EFPC periphyton were similar to previous measurements made recently. Brushy Fork (reference) periphyton had a somewhat elevated mean chlorophyll-specific photosynthesis as a result of a single high value $(1.35 \mathrm{FgC} / \mathrm{Fgchl} / \mathrm{h}$ ) from one of the four rocks that were sampled. The other three rocks produced chlorophyll-specific photosynthesis values consistent with historical values, indicating that the one high value was anomalous.

Table 5.1. Means and standard errors for biomass, photosynthesis, and chlorophyll-specific photosynthesis rates of periphyton collected from EFPC and Brushy Fork, May 16, 2000

\begin{tabular}{|c|c|c|c|}
\hline Site & $\begin{array}{l}\text { Algal biomass } \\
(\text { Fg chla/cm²) }\end{array}$ & $\begin{array}{l}\text { Photosynthesis } \\
\left(\mathrm{FgC}_{\mathrm{cm}} / \mathrm{h}\right)\end{array}$ & $\begin{array}{l}\text { Chlorophyll-specific } \\
\text { photosynthesis } \\
\text { (FgC/Fgchla/h) }\end{array}$ \\
\hline EFK 24.4 & $55.6 \pm 10.9$ & $12.75 \pm 2.42$ & $0.26 \pm 0.05$ \\
\hline EFK 23.4 & $35.4 \pm 4.3$ & $9.12 \pm 0.48$ & $0.27 \pm 0.03$ \\
\hline EFK 6.3 & $24.3 \pm 3.2$ & $6.44 \pm 0.21$ & $0.28 \pm 0.04$ \\
\hline BFK 7.6 & $7.1 \pm 2.0$ & $3.17 \pm 1.12$ & $0.55 \pm 0.27$ \\
\hline
\end{tabular}

Note $:$ EFK = East Fork kilometer, BFK = Brushy Fork kilometer 


\subsection{Benthic Macroinvertebrate Community (J. G. Smith)}

\subsubsection{Introduction}

The objectives of the benthic macroinvertebrate task are to monitor the benthic macroinvertebrate community in EFPC in order to provide information on the ecological condition of the stream, and to evaluate the responses of macroinvertebrates to operational changes, abatement activities, or remedial actions at the Y-12 Plant as a measure of the effectiveness of these actions. To meet these objectives, quantitative benthic macroinvertebrate samples have been collected at least twice each year (April and October) since 1985 from four sites in EFPC (EFKs 24.4, 23.4, 18.7, and 13.8), although only EFKs 24.4, 23.4, and 13.8 samples are routinely processed. Additionally, samples are collected once annually from EFK 6.3 (in April) and processed. Since 1986, up to two reference sites unimpacted by industrial discharges have also been monitored, including one site each on Brushy Fork (BFK 7.6) and Hinds Creek (HCK 20.6) (Figs.1.1 and 1.2). In addition to routine benthic macroinvertebrate community studies, an in situ bioassay, using a locally available clam as the test organism, is also conducted periodically.

\subsubsection{Results/Progress}

The routine collection of quantitative benthic macroinvertebrate samples at five EFPC and two reference sites was completed as scheduled in April. The results for April and October sampling periods from 1985 through 1999 are summarized in Figure 5.1. These results continue to show that the macroinvertebrate community at EFK 23.4 and EFK 24.4 is significantly degraded relative to the reference sites and to EFK 13.8. These two sites are characterized by low numbers of total taxa and few pollution sensitive taxa. However, the trend of gradually improving conditions as previously observed, continued in October 1999. Furthermore, in terms of these two normally sensitive metrics (total richness and richness of pollution sensitive taxa), EFK 23.4 and EFK 24.4 continue to exhibit little difference between one another, a trend that began after 1997. The results for EFK 13.8 appear to indicate that this site may be receiving additional impacts (i.e., declines in total richness relative to the reference sites). Because EFK 23.4 and EFK 24.4 have not experienced equivalent declines in richness metrics, these results suggest that some additional perturbation may be occurring downstream of the Y-12 Plant.

An in situ clam bioassay was initiated in early June 2000. Clams were placed at three sites in EFPC (EFK 24.4, EFK 23.4, and EFK 13.8) and three reference sites [Brushy Fork (BFK 7.6), Hinds Creek (HCK 20.6), and Cox Creek (CXK 0.2)]. There are no results to report to date.

\subsection{Fish Community (M. G. Ryon)}

\subsubsection{Introduction}

Fish population and community studies can be used to assess the ecological effects of water quality and/or habitat degradation. Fish communities, for example, include several trophic levels and species that are at or near the end of food chains. Consequently, they integrate the direct effects of water quality and habitat degradation on primary producers (periphyton) and consumers (benthic invertebrates) that are utilized for food. Because of these trophic interrelationships, the well-being of fish populations has 

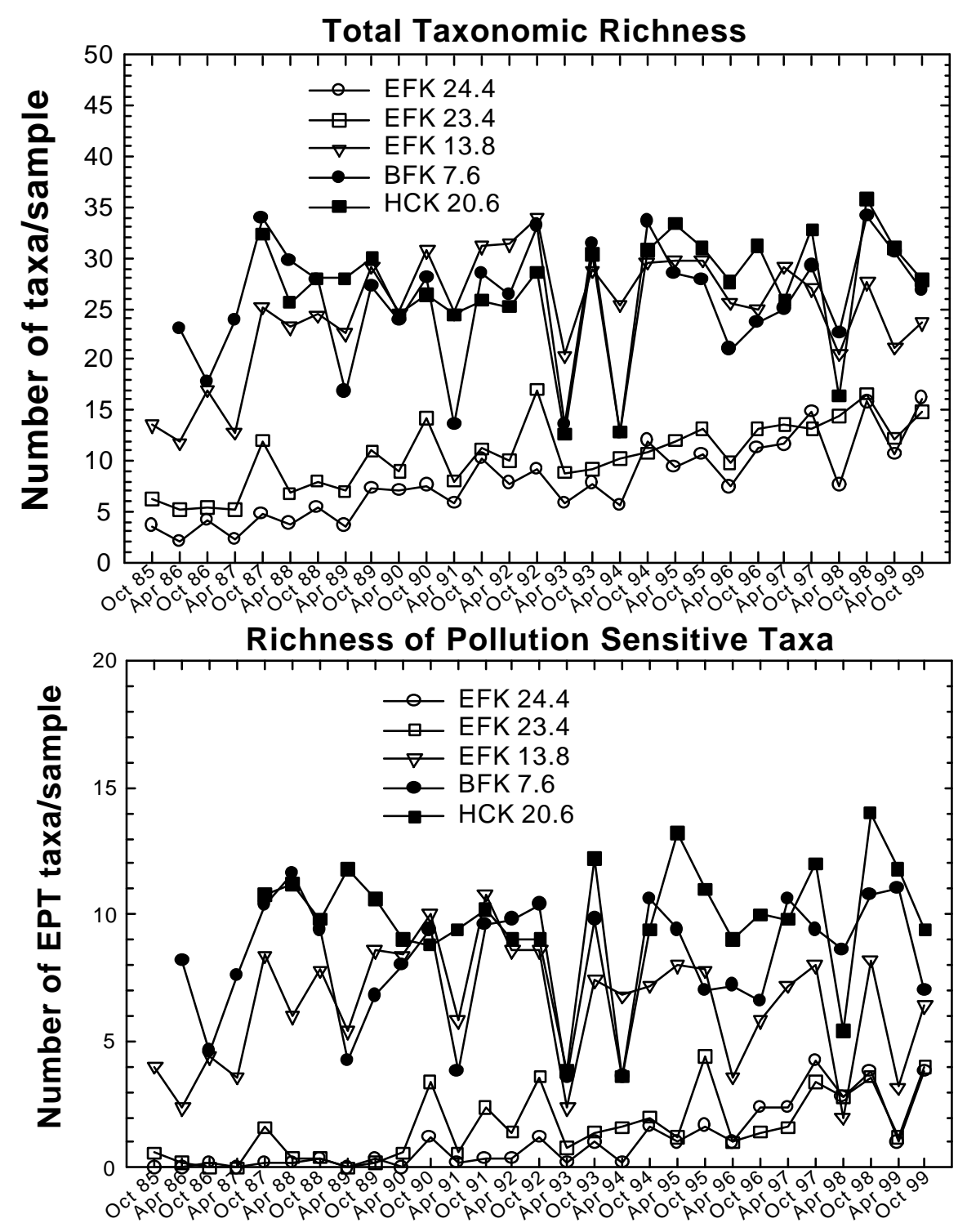

Sampling period

Fig. 5.1. Mean values for total taxonomic richness (number of taxa/sample) and taxonomic richness of the pollution sensitive Ephemeroptera, Plecoptera, and Trichoptera (number of EPT taxa/sample) of the benthic macroinvertebrate communities in EFPC and reference sites in Brushy Fork (BFK 7.6) and Hinds Creek (HCK 20.6) from October 1985 through October 1999. 
often been used as an index of water quality. Moreover, statements about the condition of the fish community are easily understood by the general public.

The two primary activities conducted by the Fish Community Studies task in EFPC are: (1) biannual, quantitative estimates of the fish community at six EFPC sites and two reference stream sites; and (2) investigative procedures in response to fish kills near the Y-12 Plant. The quantitative sampling of fish populations is conducted by electrofishing during the March-April and September-October periods. The resulting data are used to estimate population size (numbers and biomass per unit area), determine length frequency, estimate production, and calculate Index of Biotic Integrity values. Fish kill investigations are conducted in response to chemical spills, unplanned water releases, or when dead fish are observed in EFPC. The basic tool used for fish kill investigations is a survey of upper EFPC (above Bear Creek Road to the N/S Pipes) in which numbers and locations of dead, dying, and stressed fish are recorded. This baseline is supplemented by special toxicity tests, histopathological examinations, and water quality measurements in an effort to determine the cause(s) of the observed mortality.

\subsubsection{Results/Progress}

This quarter, quantitative fish community sampling was completed for the EFPC sites, and the reference sites as per the plan schedule. Data from these quantitative surveys of EFPC sites were entered into computer databases, and are being processed through quality assurance procedures. No reportable fish kills were investigated during this quarter.

\section{DATA MANAGEMENT ( $S$. W. Christensen)}

\subsection{Introduction}

Environmental Compliance projects are required by provisions of the Oak Ridge Reservation Federal Facilities Agreement (FFA) and the State of Tennessee Oversight Agreement (TOA) to transmit their data to the Oak Ridge Environmental Information System (OREIS). BMAP data managers receive data packages from the PIs of the other tasks, transform the data into appropriate OREIS formats, and facilitate the data transfer to OREIS. This task also administers the BMAP workstation.

\subsection{Results/Progress}

During the $2^{\text {nd }}$ quarter 2000, data managers worked with OREIS to determine solutions for issues associated with OREIS' revision of the Ready-to-Load (RTL) specifications, primarily involving conversion from SAS to ASCII formats for RTL transmittals to OREIS. Surface water toxicity monitoring data from July 1999 through March 2000 were resubmitted to OREIS following resolution of these issues. Benthic macroinvertebrate data from 1991-1993 and 1998 through 1999 were submitted during this quarter as well. 


\section{THIRD QUARTER 2000 FIELD ACTIVITIES}

This section of the Y-12 BMAP quarterly report is meant to provide information to the Y-12 Environmental Compliance Office and other interested parties concerning BMAP plans for field activities in upper EFPC and adjacent environs during the upcoming calendar quarter.

Toxicity - Ambient water samples from EFK 24.1 and effluent samples from Outfall 201 will be evaluated for toxicity to Ceriodaphnia dubia during the $3^{\text {rd }}$ quarter 2000.

Bioindicators - A medaka embryo-larval TIE on ambient water samples from EFPC will be continued during the $3^{\text {rd }}$ quarter 2000.

Bioaccumulation - Sampling of channel catfish for the bioaccumulation task will be conducted during the $3^{\text {rd }}$ quarter 2000 from the Clinch River/Watts Bar Reservoir downstream from the mouth of EFPC.

Community Studies - Sampling for chlorophyll and photosynthesis at EFK 24.4, 23.4, and Brushy Fork will occur in August or September; the specific date will depend on flow conditions. Benthic invertebrate sampling will occur in April. An in situ clam bioassay continues in upper EFPC during this quarter. During the last month of the quarter, fish community sampling will be initiated in the EFPC drainage as part of the fall sampling activity.

\section{REFERENCES}

Benoit, D. A., G. W. Holcombe and R. L. Spehar. 1991. Guidelines for conducting early life stage toxicity tests with Japanese Medaka (Oryzias latipes). EPA/600/3-91/063. Environmental Research Laboratory - Duluth. Duluth, Minnesota.

Loar, J. M., S. M. Adams, L. J. Allison, J. M. Giddings, J. F. McCarthy, G. R. Southworth, J. G. Smith and A. J. Stewart. 1989. The Oak Ridge Y-12 Plant Biological Monitoring and Abatement Program for East Fork Poplar Creek. ORNL/TM-10265. Oak Ridge National Laboratory. Oak Ridge, Tennessee. 